\title{
How Much Did China's WTO Accession Increase Economic Growth in Resource-Rich Countries?
}

\author{
by \\ Thomas Barnebeck Andersen, \\ Mikkel Barslund, \\ Casper Worm Hansen, \\ Thomas Harr \\ and \\ Peter Sandholt Jensen
}

Discussion Papers on Business and Economics

No. $15 / 2013$

FURTHER INFORMATION

Department of Business and Economics

Faculty of Business and Social Sciences

University of Southern Denmark

Campusvej 55

DK-5230 Odense M

Denmark

Tel.: +45 65503271

Fax: +456550 3237

E-mail: lho@sam.sdu.dk

http://www.sdu.dk/ivoe 


\title{
How Much Did China's WTO Accession Increase Economic Growth in Resource-Rich Countries?*
}

\author{
Thomas Barnebeck Andersen* \\ Department of Business and Economics, University of Southern Denmark \\ Campusvej 55, DK-5230 Odense M, Denmark \\ Mikkel Barslund \\ Center for European Policy Studies, Congresplaats 1, 1000 City of Brussels, Belgium
}

Casper Worm Hansen

Department of Economics, Aarhus University, Fuglesangs Allé 4, DK-8210 Aarhus V, Denmark

Thomas $\operatorname{Harr}^{\dagger}$

Standard Chartered Bank, Marina Bay Financial Centre (Tower 1), 8 Marina Boulevard, Level 18, Singapore 018981

Peter Sandholt Jensen

Department of Business and Economics, University of Southern Denmark

Campusvej 55, DK-5230 Odense M, Denmark

September 2013

\begin{abstract}
We provide an estimate of China's impact on the growth rate of resource-rich countries after its WTO accession on 11 December 2001. Our empirical approach follows the logic of the differences-in-differences estimator. In addition to temporal variation arising from the WTO accession, which we argue was exogenous to other countries' growth trajectories, we exploit spatial variation arising from differences in natural resource wealth. This allows us to compare changes in economic growth in the post-accession period relative to the pre-accession period between countries that were able to benefit from the surge in demand for industrial commodities brought about by China's WTO accession and countries that were less able to do so. We find that roughly one tenth of average annual post-accession growth in resource-rich countries was due to China's increased appetite for commodities. We use this finding to inform the debate about what will happen to economic growth in resource-rich countries as China rebalances and its demand for commodities weakens.
\end{abstract}

JEL Codes: F4, F62

\footnotetext{
* We thank Nikolaj Malchow-Møller for useful comments.

* Correspondence to: barnebeck@sam.sdu.dk.

${ }^{\dagger}$ Disclaimer: Thomas Harr is an employee of Standard Chartered Bank, Singapore ("the Bank"). Contents in this article are the authors' personal views and do not represent the views of the Bank.
} 


\section{Introduction}

Many countries, and in particular emerging markets, have experienced extraordinarily rapid economic growth during the past decade or so. ${ }^{1}$ This paper quantifies the extent to which natural resources have contributed to this growth. We focus on the period 2002-08, i.e. the period which began immediately after China entered the WTO and which ended just as the global financial crisis started to discharge its depressive force in earnest. We focus on this particular period because commodity price inflation accelerated around 2002 and then turned negative in 2008, but also because this period allows us to combine plausibly exogenous temporal variation in commodity demand with plausibly exogenous spatial variation in the supply of natural resources for purposes of identification.

More specifically, our empirical approach follows the logic of the differences-in-differences estimator. We exploit temporal variation arising from China's WTO accession on 11 December 2001 and spatial variation arising from differences in the availability of natural resources such as coal, oil, minerals, etc. This allows us to compare changes in economic growth in the postaccession period (2002-2008) relative to the pre-accession period (1992-2001) between countries that stood to benefit from the increase in demand for industrial commodities brought about by China's WTO accession and countries that did not. ${ }^{2}$

For our full sample of 162 countries, we find that the increased demand for various raw materials induced by China's WTO accession increased average annual growth by about 0.27 percentage points. In relative terms - i.e. as a share of total growth - this translates into 8.62\%. Put differently, slightly less than one tenth of actual average annual growth between 2002 and 2008 was, according to our calculations, due to China's increased demand for commodities. We perform similar calculations for all major regions of the world. For the sub-Saharan African sample, for instance, we find that China's WTO accession increased economic growth by 0.29 percentage points in absolute terms and $10.74 \%$ in relative terms.

\footnotetext{
${ }^{1}$ Even Africa has joined the club of fast-growing regions. The IMF's World Economic Outlook (October 2012) projects Africa's real GDP growth for 2013 to be $5.7 \%$.

2 To minimise measurement error in economic growth rates, we follow the lead of Henderson et al. (2012) and construct adjusted growth rates using earthlights observable from outer space. This adjustment is only possible for the period 1992-2008, which explains the length of our sample window. We do, however, also report results from unadjusted growth.
} 
The credibility of our empirical strategy, and consequently of our results, centres on the assumption that we are able to control for all other changes that (i) occurred around the time of China's WTO accession, and that at the same time (ii) correlate with natural resource availability and (iii) affect economic growth. In other words, if a potential change is thought to threaten our identification strategy, it must be the case that this change simultaneously fulfills (i)-(iii); if it fails to do so, it cannot, as a matter of logic, constitute a threat to the validity of our approach.

Investigating the extent to which natural resources have contributed to economic growth is interesting for at least two reasons. First, it speaks to the 'metals or management' debate, which revolves around the relative importance of improved economic management versus the surge in international commodity prices as the key driver of growth in resource-rich emerging markets (Beny \& Cook, 2009; Andersen \& Jensen, 2013). ${ }^{3}$ Finding, as we do, a fairly small impact from natural resource availability is evidence against the view that strong economic growth in emerging markets over the last decade has been driven primarily by the boom in commodities. ${ }^{4}$ Second, it speaks to the ongoing debate about how commodity exporters will be impacted as the Chinese economy rebalances. China has begun the process of shifting its developmental model from one driven by exports and investment to a more sustainable model driven in large part by domestic consumption (Bettis, 2013). There is no doubt that we will see significantly slower Chinese growth as a consequence. ${ }^{5}$ This will affect economies around the world; it will in particular hurt exporters of raw materials such as Africa, Australia, and Latin America. ${ }^{6}$ Pessimists, such as Ocampo \& Erten (2013), even argue that it will mean the end of "income

\footnotetext{
${ }^{3}$ Conventional wisdom in the financial press appears to be that resource-rich countries have enjoyed a long boom thanks to China's hunger for commodities; see e.g. Financial Times, 1 July 2013, "China's long march."

${ }^{4}$ This squares well with Andersen \& Jensen (2013), who find that 'economic management' explains a large part of Africa's recent growth spurt.

${ }^{5}$ The World Bank estimates that Chinese growth will slow to between $6 \%$ and $7 \%$ by the end of the decade; see Financial Times, 15 April 2011, "China enters era of slower growth." This compares with an average of 10.2\% over the last decade.

${ }^{6}$ The IMF has attributed much of this growth to China's increasing appetite for natural resources, especially energy and metals. Fund researchers find that when demand in China falls, so do commodity exports from commodityexporting countries. On average, 1 percentage point decline in Chinese demand translates into a fall in commodity exports of about $0.4 \%$. Financial markets clearly see eye-to-eye with the IMF on the prominence of Chinese demand for commodity exporting countries. For instance, in a week when the leaders of Australia and New Zealand happened to be in China to sign trade deals, the former two countries' currencies rose by $2 \%$ and $3 \%$, respectively. The following week, both currencies plummeted in accord as China released figures showing that the economy had grown at a much slower pace than expected; see Financial Times, 24 April 2013, "Hidden benefits of China's slower growth."
} 
convergence worldwide." We use our empirical model to inform this debate. Indeed, our results suggest that commodity producers will be able to withstand slower Chinese growth in coming decades.

The paper is structured as follows. Section 2 discusses China's WTO accession, with the aim of establishing (i) that it caused a commodity boom and (ii) that it was exogenous to other countries' growth trajectories. Section 3 discusses the empirical strategy in detail, while data are discussed in Section 4. Section 5 presents our results. Section 6 addresses economic significance using different counterfactual scenarios, and discusses what happens when China slows. Concluding remarks are offered in Section 7.

\section{China's WTO accession as the cause of the recent commodity boom}

A commodity price boom that was unprecedented in magnitude and duration preceded the recent global economic crisis (Erten \& Ocampo, 2012). Most commodity analysts agree that a critical factor behind the rise in commodity prices was the strength of Chinese demand for industrial commodities (Ocampo \& Erten, 2013; Yu, 2011). According to the IMF's World Economic Outlook (2006, Chapter 6), China contributed almost all of the increase in world consumption of nickel and tin during 2002-05. In the cases of lead and zinc, China's contribution even exceeded net world consumption growth. For the two most widely traded base metals, aluminum and copper, as well as for steel, the contribution of China to world consumption growth was about 50\%. According to the same IMF report, China's contribution to world consumption growth of aluminum increased by 10 percentage points, copper by 8 , lead by 68 , nickel by 75 , steel by 16 , tin by 52 , and zinc by 71 percentage points, compared to the period 1993-2002. For oil, the comparable number was 9 percentage points. ${ }^{7}$ The important thing to notice here is that China's consumption of industrial commodities picked up strongly following its entry into the WTO on 11 December 2001.

An important steppingstone on China's long walk towards the WTO was the trade deal signed by China and the US on 15 November 1999. By the time the deal was signed it was not

\footnotetext{
${ }^{7}$ Oil efficiency is also much lower in China than in the US (Beirne et al., 2013).
} 
certain that it would go through the US Congress. ${ }^{8}$ Moreover, 24 out of 135 member countries, including the EU, still had not agreed on entry terms with China at the time. ${ }^{9}$ However, on 24 May 2000, some six months after the signing of the trade deal, the US House of Representatives passed the bill to give China permanent trade status with the US. And since the EU had reached a deal with China during the previous week, Chinese entry into the WTO was expected from that point on. The actual date of entry was unknown, however, and it was not until 17 September 2001 that the final negotiations were concluded.

The crucial issue in connection with joining the WTO was that membership helped China lock in the gains from rule-based multilateral trade; at the same time, it greatly reduced concerns about market access (Wang, 2007). ${ }^{10}$ This gave investors and traders incentives to exploit the economies of scale offered by China's deeper integration into the world economy. WTO entry was also a lever its reform-oriented leadership could use to complete the transition to a more market-oriented economy (Lardy, 2001). The WTO accession led to long-term investments in manufacturing capacity and infrastructure, which strongly increased demand for metals such as copper, aluminum, and steel (Coates \& Luu, 2012; Heap, 2005). The effect of China's WTO accession on commodity demand is distinctly visible in prices; Figure 1 shows that real commodity prices picked up sharply after 2002 .

\section{[Figure 1 about here]}

The critical aspect of China's WTO accession for the purposes of the empirical analysis below is that it generated an increase in demand for commodities that is plausibly exogenous to

\footnotetext{
${ }^{8}$ Under American law at the time, normal trade relations with China were conditional on an annual vote by Congress that was heavily influenced by human rights issues in China. Congress had to agree to change the law, since this annual vote was incompatible with WTO rules. See The Economist, 18 November 1999, "The remaining hurdles."

${ }^{9}$ And even if Congress and member countries endorsed the deal, China still had to deliver on its liberalisation promises, which again was not a foregone conclusion. There was resistance from hardliners and speculation that the unsettling consequences of WTO entry would spark social unrest. See The Economist, 18 November 1999, "China opens up."

10 The WTO accession involved, among many other things, national treatment of foreign-funded firms and greater opportunities for exporters of services. In manufacturing, China had to abolish non-tariff barriers and reduce tariffs. It also meant that China had to adhere to the principle of non-discrimination and had to liberalise investment rules. Moreover, WTO accession led to increased transparency and predictability of Chinese trade policy (Ianchovichina \& Walmsley, 2005).
} 
the growth trajectory of other countries. This means that we can potentially use this variation in commodity demand as part of an identification strategy. The next section outlines our approach in more detail.

\section{Empirical strategy}

In order to understand our empirical approach, consider the following differences-indifferences type specification:

$$
g y_{i t}=\beta_{0}+\beta_{1} \cdot N R_{i} \cdot D_{t}+\sum_{j=1}^{J} \beta_{2 j} \cdot D_{t} \cdot R_{j}+c_{i}+\operatorname{error}_{i t}
$$

In equation (1), $t=1,2\left(t=1\right.$ refers to the period 1992-2001 and $t=2$ refers to 2002-08), $g y_{i t}$ is average annual growth in real GDP per capita in country $i, N R_{i}$ measures the natural resource endowment, $D_{t}$ is a binary indicator that takes the value 1 in the post WTO-accession period and 0 otherwise, $R_{j}$ is a regional indicator, and $c_{i}$ is a country fixed effect. Note that by including $R_{j}$, we allow each region to have its own region-specific time trend; and note also that by including a country fixed effect, $c_{i}$, we pick up time-invariant as well as slow-moving growth influences. The parameter of interest is $\beta_{1}$, which measures the impact of natural resource availability on economic growth in the post WTO-accession period relative to the pre-accession period. ${ }^{11}$ This means that we can estimate by how much the impact of natural resource availability on economic growth changed after China's WTO accession.

We also estimate a model with a lagged dependent variable but without the country fixed effect. That is, we also estimate the following specification:

$$
g y_{i t}=\beta_{1} \cdot N R_{i} \cdot D_{t}+\sum_{j=1}^{J} \beta_{2 j} \cdot D_{t} \cdot R_{j}+\beta_{3} \cdot y_{i t-1}+\text { error }_{i t}
$$

where $y_{i t-1}$ is (log of) lagged real GDP per capita. A few comments are in order. First, the lagged dependent variable in equation (2) has a theoretical interpretation in terms of transitional

\footnotetext{
11 The fixed effects estimator does not allow us to identify the impact of $N R_{i}$, as it cannot be distinguished from the country fixed effect $c_{i}$. All we can hope for is identification of the impact relative to the pre-accession base period.
} 
dynamics (Barro \& Sala-i-Martin, 2004). Second, as equations (1) and (2) are not nested, the most obvious thing to do would be to ensure nesting by adding a country fixed effect to equation (2). Unfortunately, the conditions for consistent estimation in this case are much more demanding that those required for equations (1) and (2); but, fortunately, equations (1) and (2) have a useful bracketing property in the sense that they bound the 'true' effect (Angrist \& Pischke, 2009). ${ }^{12}$

As explained briefly in Section 1, the requirement for identification is that no other changes occurred around 2002 that both correlate with natural resource availability and affect economic growth; stated more formally, it must be the case that $\operatorname{Cov}\left(N R_{i} \cdot D_{t}, \operatorname{error}_{i t}\right)=0 .{ }^{13}$ This condition is more likely to be fulfilled when region-specific time trends are included, as in equations (1) and (2), than if we had only included a global time trend (i.e. only included $D_{t}$ as opposed to $D_{t}$ interacted with all regional indicators). The region-specific trends, for example, pick up regional macroeconomic policy improvements.

It is worth stressing the advantages offered by equations (1) and (2). Consider for example the study by Ahuja \& Nabar (2012) in which the authors ask whether a fall in China's investment rate will reduce global economic growth. They construct a measure of Chinese influence on country $i$ as the product of Chinese fixed investment in year $t$ times country $i$ 's export to China as a fraction of GDP. Both of these constituent variables are likely to be endogenous to country $i$ 's growth trajectory. Export to China as a fraction of GDP, an outcome variable, is endogenous on account of both simultaneity (higher growth in country $i$ is likely to diminish export/GDP) and omitted variables bias (many factors that influence export also influence growth). Chinese fixed investment may be endogenous because geo-political tensions, for example, may affect both the timing of Chinese investments as well as individual countries' growth trajectories via commodity prices. Such endogeneity concerns are likely to be eliminated in our differences-indifferences setup since we rely on plausibly exogenous temporal variation in export demand and use plausibly exogenous spatial variation in export supply.

\footnotetext{
12 This of course requires that either equation (1) or equation (2) is the 'true' population regression model.

13 The transparency of our identification strategy should be compared to the usual VAR/VECM approaches found in the literature, which rarely discusses the assumptions behind identification (e.g. Arora \& Vamvakidis, 2011). These approaches mechanistically apply some ad hoc decomposition of the innovations in order to identify the impulse responses.
} 


\section{Data}

It is well known that GDP data from many countries are badly measured. Indeed, for some regions one may reasonably doubt that GDP data make much sense (Jerven, 2013). In Zambia, for example, just one man was responsible for preparing national income accounts in 2010; at the same time, incentives were actually biased against producing estimates. ${ }^{14}$ Moreover, data collection is politicised with measurement often "taking the backseat" (Jerven, 2013).

Since results can be no better than the quality of the data that goes in to the analysis, we try to address these data issues by following the lead of Henderson et al. (2012) in producing adjusted real GDP per capita growth rates by employing satellite data on the amount of earthlights that can be observed from outer space at night. Consumption of nearly all goods in the evening requires lights. As income rises, so does light usage per person. And since several error-prone measures are better than one, empirical researchers can combine administrative real GDP data with lights at night to reduce measurement error. Consequently, the growth observations used below are a convex combination (weight: 0.5) of observed real GDP per capita growth and the fitted values from a regression of this variable on growth in night lights (for further details, see Henderson et al., 2012). ${ }^{15}$ The observed real GDP per capita measure is in local currency units and taken from the World Bank's World Development Indicators. We also report results using only unadjusted growth rates. The earthlight adjustment is only possible for the period 1992-2008, which explains the length of our dataset.

Our measure of natural resource availability is taken from the World Development Indicators 2013. The data build on the methodology used in the World Bank (2007) project "The Changing Wealth of Nations", which assigned dollar values to stocks of the main energy resources (oil, gas, and coal), ten metals and minerals (bauxite, copper, gold, iron ore, lead, nickel, phosphate rock, silver, tin and zinc), and timber (roundwood). We employ the total rent

\footnotetext{
${ }^{14}$ For many African countries, base years for GDP series even date back some 20 years.

${ }^{15}$ Earthlights data were downloaded from http://www.econ.brown.edu/faculty/henderson/lights_hsw_data.html on 27 July 2013.
} 
measure, which is the sum of all rents (i.e. the sum of oil, natural gas, coal, metals \& mineral, and timber rents). Total rent is expressed as a percentage of nominal GDP. ${ }^{16}$

The specific methodology used by the World Bank in the construction of total rent is as follows. Non-renewable natural resource wealth should, in theory, be calculated as the present discounted value of economic rents over the life time of the resource, i.e. as $V_{t}=\sum_{i=t}^{t+T-1} \pi_{i} \cdot q_{i}$. $(1+r)^{-(i-t)}$, where $\pi_{i}$ is unit rent (i.e., unit price minus unit cost), $q_{i}$ is the level of production, $r$ is the social discount rate, and $T$ is the life time of the resource. Since future rents are unknown, the World Bank calculated resource wealth on the assumption of constant per-period total rent, i.e. $\pi_{i} \cdot q_{i}=\pi_{t} \cdot q_{t}$ for all $i$. This means that the actual formula used in the calculation of rent is $V_{t}=\pi_{t} \cdot q_{t} \cdot\left(\left((1+r)^{T}-1\right) / r \cdot(1+r)^{T-1}\right)$. In the specific calculations performed by the World Bank, $d=0.04$ and $T=25 .{ }^{17}$ In the estimations below, we use the calculations for the year 2000, i.e. $t=2000$ (using $t=1995$ instead gives similar results, statistically speaking, to those reported below). This gives us a measure of natural resource availability calculated on the basis of year 2000 prices, costs and production levels, i.e. prices, costs and production levels in force prior to China's WTO accession. Figure 2 provides a map of natural resource availability according to the total rent measure.

[Figure 2 about here]

We use the World Bank's regional classification code to construct regional indicators. These are East Asia \& Pacific (EAS), Europe and Central Asia (ECS), Latin America \& Caribbean (LCN), Middle East \& North Africa (MEA), North America (NAC), South Asia (SAS), sub-Saharan Africa (SSF).

Table 1 reports the summary statistics for the variables used in the main analysis. Note that we have balanced the panel, as an unbalanced panel fits uncomfortably with the differences-in-differences approach.

\footnotetext{
16 Total rent is denoted NY.GDP.TOTL.RT.ZS in the World Development Indicators.

${ }^{17}$ If $T=25$ is larger than the reserves-to-production ratio, $T$ is set equal to the latter value.
} 
[Table 1 about here]

\section{Results}

Table 2 reports results from the fixed effects estimation of equation (1). Column 1 is the estimation for the full sample with 162 countries. The point estimate of $\beta_{1}$ equals 0.0335 and it is significant at the $5 \%$ level. The simple fixed effect specification explains more than $44 \%$ of the variation in economic growth. In the remaining columns 2-8, we exclude geographical regions one-by-one in order to check robustness of the estimate in column 1. With the exception of column 3, where the 40 countries belonging to Europe \& Central Asia (ECS) are excluded, point estimates are always significant at 5\%. In column 3, the point estimate drops by about one third and precision also drops a bit. Overall, the estimate in column 1 appears fairly robust. In the table, point estimates are bounded by the interval [0.0213-0.0502].

\section{[Table 2 about here]}

In Table 3 we report results from a pooled OLS estimation of equation (2). The point estimate of $\beta_{1}$ in the full sample of 162 countries equals 0.0267 and is significant at $1 \%$, cf. column 1. In the table, point estimates are always bounded by the interval [0.0255-0.0313]. Moreover, with the exception of column 8 where the 45 countries belonging to sub-Saharan Africa (SSF) are excluded, point estimates are always significant at 5\%.

\section{[Table 3 about here]}

According to the Angrist-Pischke result discussed in Section 3, the full sample estimates in Tables 2 and 3 (i.e. the estimates found in the first column of both tables) brackets the 'true' value of $\beta_{1}$. That is, the interval [0.0267-0.0335] pins down the value of $\beta_{1}$. For completeness, and despite the bias induced by the correlation between the fixed effect and lagged dependent variable, we also estimate the fixed effects model with a lagged dependent variable; results are 
reported in Appendix Table A1.18 Inspection of Table A1 reveals that the fixed effects estimator with lagged dependent variable yields an estimate of $\beta_{1}=0.0342$ for the full sample. Interestingly, this is only slightly above the upper boundary of the 'true' interval as defined by the Angrist-Pischke result. In sum, all three models yield results that are broadly in accordance, and we can with some confidence conclude that the 'true' estimate of $\beta_{1}$ is about 0.03 . To economise on space, we only report results using equation (1) from now on. Estimation of equation (2) yields similar results and conclusions.

If instead of adjusted growth rates we use unadjusted growth rates (calculated using real GDP per capita in local currency units), we get point estimates that are somewhat higher and less precisely estimated, cf. Table 4. Reduced signal-to-noise ratios, and thus less precisely estimated parameters, are exactly what we would expect with unadjusted growth rates. In the full sample associated with column 1 of Table 4 , for example, we get a $\beta_{1}$ value of 0.0525 that is significant at $10 \%$.

\section{[Table 4 about here]}

In the Appendix, we shrink the sample window from 1992-2008 to 1993-2007 to see whether our results are in any way dependent on our choice of sample window. Table A2 (which should be compared to Table 2) reports results with adjusted growth for the sample period 1993-2007. As is evident upon inspecting the table, this change of sample period is not wholly innocuous. While precision is roughly unchanged, point estimates are reduced and, as a consequence, $t$-values drop. However, point estimates remain marginally significant. The optimistic note from this exercise is therefore that a 'true' estimate of $\beta_{1}=0.03$ appears quite robust.

In the Appendix, we also construct a resource dummy, which is equal to 1 if the country has positive resource rent. In our sample of 162 countries, 17 countries have no resource rent at all. With the resource dummy, results are always significant at 5\%, cf. Table A3.

\footnotetext{
${ }^{18}$ The estimating equation in this case is $g y_{i t}=\beta_{0}+\beta_{1} \cdot N R_{i} \cdot D_{t}+\sum_{j=1}^{J} \beta_{2 j} \cdot D_{t} \cdot R_{j}+\beta_{3} \cdot y_{i t-1}+c_{i}+$ error $_{i t}$.
} 


\section{Counterfactual scenarios}

In this section we compare actual with counterfactual growth, the latter being the growth rate in resource-rich countries during 2002-08 had there been no China-induced increase in demand for natural resources. That is, our counterfactual scenario is a world in which China did not join the WTO. Consequently, we define $C C$ as the difference between actual and counterfactual average annual real GDP per capita growth during the period 2002-08. Formally, we have

$$
\begin{gathered}
C C=\frac{1}{N} \cdot \sum_{i=1}^{N} g y_{i 2}-\frac{1}{N} \cdot \sum_{i=1}^{N}\left\{g y_{i 2}-\beta_{1} \cdot N R_{i}\right\} \Leftrightarrow \\
C C=\beta_{1} \cdot \frac{1}{N} \sum_{i=1}^{N} N R_{i}
\end{gathered}
$$

CC measures by how much China's WTO accession increased growth in resource-rich countries relative to what growth would have been in these selfsame countries had China not entered the WTO.

Table 5 reports the computations for the seven regions as well as the full sample. For the full sample, and using $\beta_{1}=0.03$, the increased demand for various raw materials induced by China's WTO accession increased average annual growth by about 0.27 percentage points relative to counterfactual growth. Since actual growth during 2002-08 in the full sample was $3.13 \%$, we have that in proportional terms China's increased demand for commodities explains only about $(0.27 / 3.13)=8.62 \%$. Put differently, in the full sample less than one tenth of actual average annual growth between 2002-08 was, according to our calculations, due to the increase in demand for commodities that resulted from China's WTO accession.

\section{[Table 5 about here]}

It is of independent interest to restrict attention to the different regions, with none perhaps more interesting than sub-Saharan Africa. The African continent is rich in natural resources and has experienced rapid economic growth since China entered the WTO. Africa has about half the world's gold reserves and a third of its diamonds, not to mention copper, coltan 
and all sorts of other minerals and metals. Doing the calculation for sub-Saharan Africa with $\beta_{1}=0.03$, we find that the increased demand for industrial commodities that resulted from China's WTO accession increased economic growth by 0.29 percentage points in absolute terms and $10.74 \%$ in proportional terms. Our results thus indicate that less than $11 \%$ of Africa's spectacular growth between 2002 and 2008 was due to China's increasing appetite for industrial commodities.

As noted in Section 1, China is in the process of shifting its developmental model from one driven by exports and investment to a more balanced model driven in large part by domestic consumption. So there is no doubt that we will see significantly slower Chinese growth in the years to come. ${ }^{19}$ For example, in its July 2013 update to the World Economic Outlook, the IMF cut the growth forecast for China to 7.8\%, down from its 8.1\% outlook in April; the forecast for 2014 was cut from $8.3 \%$ to $7.7 \% .^{20}$ Slower Chinese growth will affect economies around the world. Analysts predict that it will particularly hurt exporters of raw materials such as Africa, Australia, and Latin America. ${ }^{21}$ While this is undoubtedly true, there is little or no quantitative evidence on exactly how badly they will be hurt.

The counterfactual scenarios reported in Table 5 may shed some light on the likely economic impact of a Chinese growth slowdown. Indeed, an obvious way to interpret the counterfactuals is as a rough indication of what will happen if the Chinese economy reverts to its pre-accession growth trajectory. According to this interpretation, a Chinese growth reduction should not seriously undermine the growth rate of resource-rich countries.

\section{Concluding remarks}

In this paper, we have suggested an empirical strategy that delivers an estimate of the impact of China's WTO accession on economic growth in resource-rich countries. According to our results, the Chinese WTO entry explains less than one tenth of the growth experienced by resource-rich countries since 2002. This appears to be less than conventional wisdom. The

\footnotetext{
19 The World Bank estimates that Chinese growth will slow to between $6 \%$ and $7 \%$ by the end of the decade; see Financial Times, 15 April 2011, "China enters era of slower growth.” The Economist is also confident that China's growth momentum is slowing; see The Economist, 17 August 2013, "A bubble in pessimism."

20 http://www.imf.org/external/pubs/ft/weo/2013/update/02/pdf/0713.pdf

21 See Financial Times, 15 April 2010, “China enters era of slower growth." See also Financial Times, 22 July 2013,

"China: slower but steady."
} 
Economist, for example, guestimates that around one third of Africa's growth can be explained by the boom in commodities. ${ }^{22}$

To the extent that the past is a useful guide to the future, we would not - based on our results - expect to see growth in resource-rich countries slow by much more than what is reported in Table 5. This is of course a medium-run prediction because excess capacity, built on a flawed assumption of continued double-digit Chinese growth, may lead to some short-run overshooting. Nevertheless, our results do not suggest that a Chinese rebalancing will derail economic growth in resource-abundant countries.

\footnotetext{
${ }^{22}$ The Economist, 3 December 2011, "The sun shines bright."
} 


\section{References}

Ahuja, A. and M. Nabar (2012), "Investment-Led Growth in China: Global Spillovers", IMF Working Paper 12/267, International Monetary Fund, Washington, DC.

Andersen, T.B. and P.S. Jensen (2013), “Is Africa's Recent Growth Sustainable?”, International Economic Journal, forthcoming.

Angrist, J.D. and S. Pischke (2009), Mostly Harmless Econometrics, Princeton and Oxford: Princeton University Press.

Arora, V. and A. Vamvakidis (2011), “China's Economic Growth: International Spillovers”, China \& World Economy, 19(5):31-46.

Beirne, J., C. Beulen, G. Liu and A. Mirzaei (2013), "Global Oil Prices and the Impact of China", China Economic Review, 27:37-51.

Beny, L.N. and L.D. Cook (2009), “Metals or Management? Explaining Africa's Recent Economic Growth Performance", American Economic Review, 99(2):268-74.

Bettis, M. (2013), The Great Rebalancing: Trade Conflict, and the Perilous Road Ahead for the World Economy, Princeton and Oxford: Princeton University Press.

Coates, B, and H. Luu (2012), "China's emergence in global commodity markets," Economic Roundup, 1:1-30.

Erten, B. and A. Ocampo (2012), "Super-cycles of commodity prices since the mid-nineteenth century," DESA Working Paper No. 110, United Nations Department of Economic and Social Affairs. 
Heap, A. (2005), "China - The Engine of a Commodity Super-cycle”, New York, NY: Citigroup Smith Barney, 1-24

Henderson, V., A. Storeygard and D. Weil (2012), "Measuring Economic Growth from Outer Space", American Economic Review, 102(2):994-1028.

Ianchovichina, E. and T. Wallmsley (2005), "Impact of China's WTO Accession on East Asia", Contemporary Economic Policy, 23(2):261-277.

Jerven, M. (2013), Poor Numbers: How We Are Misled by African Development Statistics and What to Do about It, Ithaca, NY: Cornell University Press.

Lardy, N. (2001), "Issues in China's WTO Accession", The US-China Security Review Commission, Testimony, 9 May.

Ocampo, J. and B. Erten (2013), “The Global Implications of Falling Commodity Prices”, Project Syndicate, 27 August.

Wang, J.-Y., (2007), "What drives China's Growing Role in Africa?", IMF Working Paper No. 07/211, International Monetary Fund, Washington, DC.

Yu, Y. (2011). "Identifying the Linkage between Major Mining Commodity Circle and China Economic Growth: Its Implications for Latin America," IMF Working Paper No. 11/86, International Monetary Fund, Washington, DC. 
Figures and Tables

Figure 1. Real commodity price indices (2005 = 100)

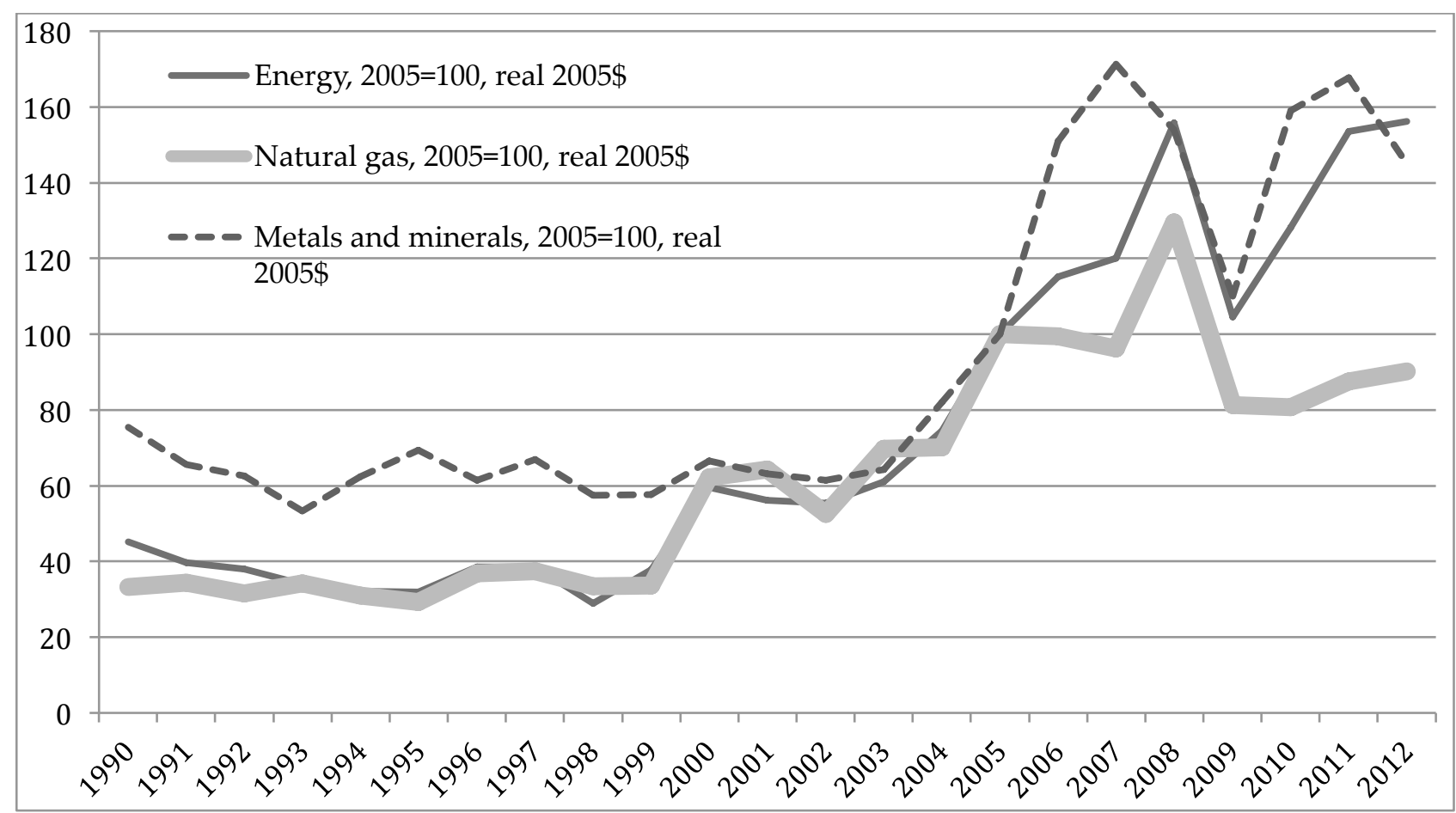

Source: World DataBank, Global Economic Monitor (GEM) Commodities < http://databank.worldbank.org>. 
Figure 2. Total Natural Resource Rents ( $\%$ of GDP, year $=2000$ )

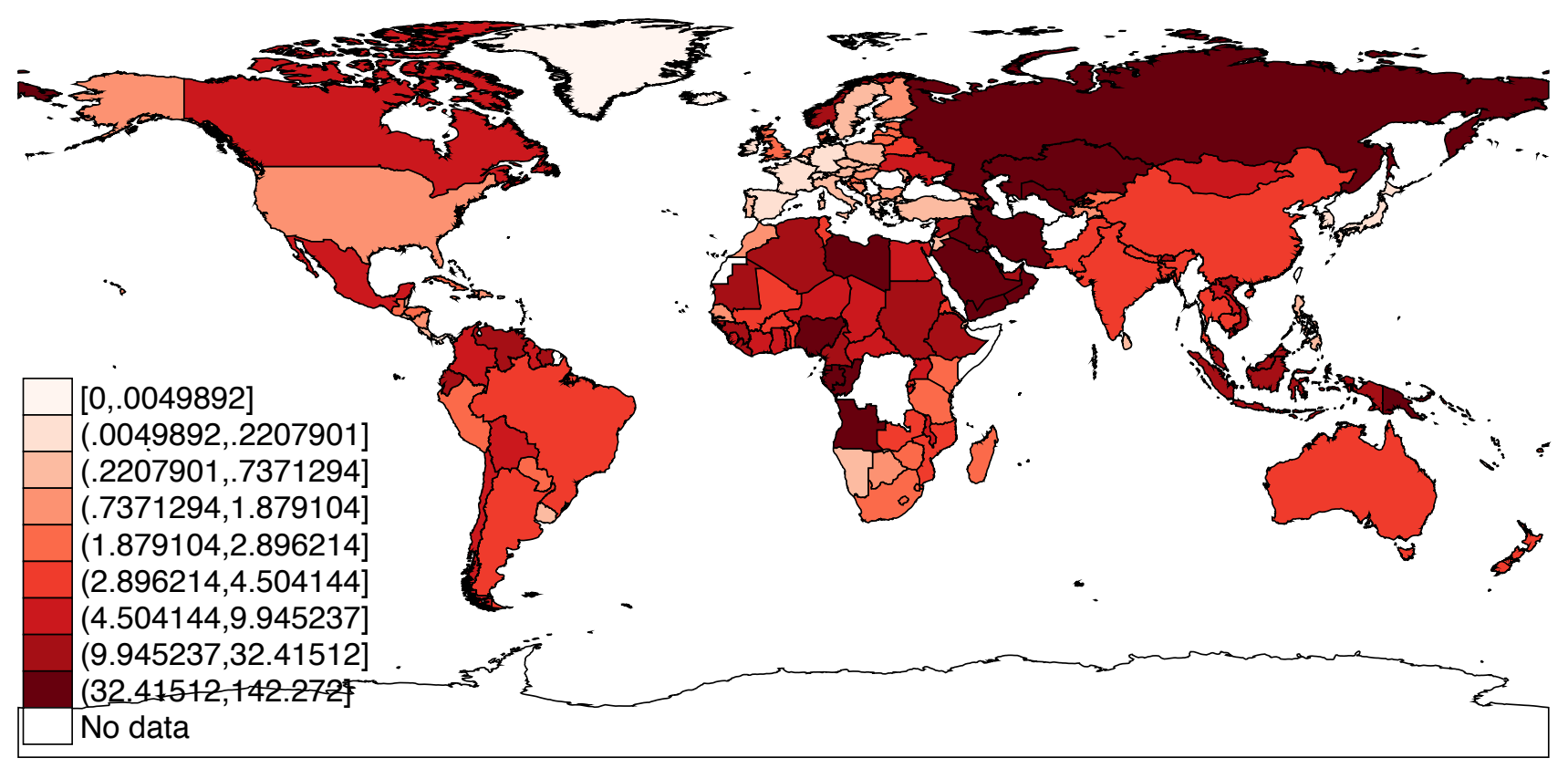

Source: World Development Indicators 2013. Variable defined as NY.GDP.TOTL.RT.ZS in the World Development Indicators 


\section{Table 1: Summary statistics}

\begin{tabular}{|c|c|c|c|c|c|}
\hline & Observation & Mean & $\begin{array}{l}\text { Standard } \\
\text { deviation }\end{array}$ & Minimum & Maximum \\
\hline \multicolumn{6}{|c|}{ Year $=1(1992-2001)$} \\
\hline Adjusted growth & 162 & 0.0155 & 0.1550 & -0.0314 & 0.1104 \\
\hline Totnatresrent & 162 & 0.0899 & 0.1784 & 0 & 1.4227 \\
\hline $\mathrm{y}$ & 162 & 10.287 & 2.2158 & 5.8512 & 16.139 \\
\hline \multicolumn{6}{|c|}{ Year $=2(2002-2008)$} \\
\hline Adjusted growth & 162 & 0.0313 & 0.1587 & -0.0407 & 0.0971 \\
\hline Totnatresrent & 162 & 0.0899 & 0.1784 & 0 & 1.4227 \\
\hline $\mathrm{y}$ & 162 & 10.440 & 2.2466 & 5.8309 & 16.604 \\
\hline
\end{tabular}




\section{Table 2: Fixed effects estimation}

Estimating equation: $g y_{i t}=\beta_{0}+\beta_{1} \cdot N R_{i} \cdot D_{t}+\sum_{j=1}^{J} \beta_{2 j} \cdot D_{t} \cdot R_{j}+c_{i}+$ error $_{i t}$

\begin{tabular}{|c|c|c|c|c|c|c|c|c|}
\hline & (1) & (2) & (3) & (4) & (5) & (6) & (7) & (8) \\
\hline VARIABLES & \multicolumn{8}{|c|}{ Adjusted growth } \\
\hline \multirow[t]{2}{*}{ Constant } & $0.0155^{* * *}$ & $0.0151^{* * *}$ & $0.0162^{* * *}$ & $0.0150^{* * *}$ & $0.0158^{* * *}$ & $0.0155^{* * *}$ & $0.0151^{* * *}$ & $0.0161^{* * *}$ \\
\hline & $(0.0008)$ & $(0.0009)$ & $(0.0008)$ & $(0.0010)$ & $(0.0008)$ & $(0.0008)$ & $(0.0008)$ & $(0.0008)$ \\
\hline \multirow[t]{2}{*}{ 2.year\#totnatresrent } & $0.0335^{* *}$ & $0.0352^{* *}$ & 0.0213 & $0.0316^{* *}$ & $0.0381^{* * *}$ & $0.0335^{* *}$ & $0.0336^{* *}$ & $0.0502^{* *}$ \\
\hline & $(0.0135)$ & $(0.0142)$ & $(0.0152)$ & $(0.0143)$ & $(0.0146)$ & $(0.0135)$ & $(0.0135)$ & $(0.0201)$ \\
\hline \multirow[t]{2}{*}{ 2.year\#EAS } & 0.0053 & & $0.0061^{*}$ & 0.0054 & 0.0050 & 0.0053 & 0.0053 & 0.0041 \\
\hline & $(0.0034)$ & & $(0.0034)$ & $(0.0034)$ & $(0.0034)$ & $(0.0034)$ & $(0.0034)$ & $(0.0035)$ \\
\hline \multirow[t]{2}{*}{ 2.year\#ECS } & $0.0237^{* * *}$ & $0.0236^{* * *}$ & & $0.0238^{* * *}$ & $0.0234^{* * *}$ & $0.0237^{* * *}$ & $0.0237^{* * *}$ & $0.0228^{* * *}$ \\
\hline & $(0.0039)$ & $(0.0039)$ & & $(0.0039)$ & $(0.0038)$ & $(0.0039)$ & $(0.0039)$ & $(0.0037)$ \\
\hline \multirow[t]{2}{*}{ 2.year\#LCN } & $0.0129 * * *$ & $0.0128^{* * *}$ & $0.0135^{* * *}$ & & $0.0127^{* * *}$ & $0.0129 * * *$ & $0.0129 * * *$ & $0.0121^{* * *}$ \\
\hline & $(0.0021)$ & $(0.0021)$ & $(0.0022)$ & & $(0.0021)$ & $(0.0021)$ & $(0.0021)$ & $(0.0022)$ \\
\hline \multirow[t]{2}{*}{ 2.year\#MEA } & $0.0085^{*}$ & 0.0082 & $0.0108^{* *}$ & $0.0089 *$ & & $0.0085^{*}$ & $0.0085^{*}$ & 0.0054 \\
\hline & $(0.0049)$ & $(0.0050)$ & $(0.0049)$ & $(0.0049)$ & & $(0.0049)$ & $(0.0049)$ & $(0.0061)$ \\
\hline \multirow[t]{2}{*}{ 2.year\#NAC } & $0.0057^{* * *}$ & $0.0057^{* * *}$ & $0.0057^{* * *}$ & $0.0057^{* * *}$ & $0.0057^{* * *}$ & & $0.0057^{* * *}$ & $0.0057^{* * *}$ \\
\hline & $(0.0000)$ & $(0.0000)$ & $(0.0000)$ & $(0.0000)$ & $(0.0000)$ & & $(0.0000)$ & $(0.0000)$ \\
\hline \multirow[t]{2}{*}{ 2.year\#SAS } & $0.0110^{* * *}$ & $0.0109^{* * *}$ & $0.0117^{* * *}$ & $0.0111^{* * *}$ & $0.0108^{* * *}$ & $0.0110^{* * *}$ & & $0.0102^{* * *}$ \\
\hline & $(0.0032)$ & $(0.0032)$ & $(0.0031)$ & $(0.0032)$ & $(0.0032)$ & $(0.0031)$ & & $(0.0034)$ \\
\hline \multirow[t]{2}{*}{ 2.year\#SSF } & $0.0086^{* *}$ & $0.0084^{* *}$ & $0.0102^{* * *}$ & $0.0088^{* *}$ & $0.0080^{* *}$ & $0.0086^{* *}$ & $0.0086^{* *}$ & \\
\hline & $(0.0036)$ & $(0.0036)$ & $(0.0035)$ & $(0.0036)$ & $(0.0036)$ & $(0.0036)$ & $(0.0036)$ & \\
\hline Observations & 324 & 280 & 244 & 260 & 292 & 322 & 312 & 234 \\
\hline R-squared & 0.447 & 0.462 & 0.361 & 0.424 & 0.450 & 0.447 & 0.444 & 0.538 \\
\hline Number of countries & 162 & 140 & 122 & 130 & 146 & 161 & 156 & 117 \\
\hline Excluded region & None & EAS & ECS & LCN & MEA & NAC & SAS & SSF \\
\hline
\end{tabular}

Notes: Asterisks $*, * *,{ }^{* *}$ denote significance at the 10, 5, and 1 percent level, respectively. All standard errors (in parenthesis) are clustered at the country level. Regional code is: East Asia \& Pacific (EAS), Europe and Central Asia (ECS), Latin America \& Caribbean (LCN), Middle East \& North Africa (MEA), North America (NAC), South Asia (SAS), sub-Saharan Africa (SSF). 
Table 3: Pooled OLS estimation

Estimating equation: $g y_{i t}=\beta_{0}+\beta_{1} \cdot N R_{i} \cdot D_{t}+\sum_{j=1}^{J} \beta_{2 j} \cdot D_{t} \cdot R_{j}+\beta_{3} \cdot y_{i t-1}+$ error $_{i t}$

\begin{tabular}{|c|c|c|c|c|c|c|c|c|}
\hline \multirow[b]{2}{*}{ VARIABLES } & (1) & (2) & (3) & (4) & (5) & (6) & (7) & (8) \\
\hline & \multicolumn{8}{|c|}{ Adjusted growth } \\
\hline \multirow[t]{2}{*}{ Constant } & $0.0115^{* *}$ & $0.0168^{* * *}$ & $0.0131^{* * *}$ & $0.0100^{*}$ & $0.0096^{*}$ & $0.0114^{* *}$ & $0.0110^{* *}$ & $0.0084^{* *}$ \\
\hline & $(0.0045)$ & $(0.0053)$ & $(0.0048)$ & $(0.0056)$ & $(0.0050)$ & $(0.0045)$ & $(0.0045)$ & $(0.0042)$ \\
\hline \multirow[t]{2}{*}{ 2.year\#totnatresrent } & $0.0267^{* * *}$ & $0.0300^{* * *}$ & $0.0206^{* *}$ & $0.0258^{* * *}$ & $0.0313^{* * *}$ & $0.0267^{* * *}$ & $0.0266^{* * *}$ & 0.0255 \\
\hline & $(0.0083)$ & $(0.0075)$ & $(0.0090)$ & $(0.0088)$ & $(0.0086)$ & $(0.0082)$ & $(0.0083)$ & $(0.0167)$ \\
\hline \multirow[t]{2}{*}{ 2.year\#EAS } & $0.0082^{* *}$ & & $0.0081^{* *}$ & $0.0088^{* * *}$ & $0.0074^{* *}$ & $0.0082^{* *}$ & $0.0086^{* * *}$ & $0.0073^{* *}$ \\
\hline & $(0.0032)$ & & $(0.0033)$ & $(0.0033)$ & $(0.0032)$ & $(0.0032)$ & $(0.0032)$ & $(0.0030)$ \\
\hline \multirow[t]{2}{*}{ 2.year\#ECS } & $0.0221^{* * *}$ & $0.0222^{* * *}$ & & $0.0228^{* * *}$ & $0.0216^{* * *}$ & $0.0221^{* * *}$ & $0.0225^{* * *}$ & $0.0215^{* * *}$ \\
\hline & $(0.0028)$ & $(0.0029)$ & & $(0.0030)$ & $(0.0029)$ & $(0.0028)$ & $(0.0028)$ & $(0.0028)$ \\
\hline \multirow[t]{2}{*}{ 2.year\#LCN } & $0.0156^{* * *}$ & $0.0157^{* * *}$ & $0.0152^{* * *}$ & & $0.0151^{* * *}$ & $0.0156^{* * *}$ & $0.0160^{* * *}$ & $0.0150^{* * *}$ \\
\hline & $(0.0021)$ & $(0.0022)$ & $(0.0022)$ & & $(0.0022)$ & $(0.0021)$ & $(0.0021)$ & $(0.0022)$ \\
\hline \multirow[t]{2}{*}{ 2.year\#MEA } & $0.0071^{*}$ & 0.0070 & $0.0077^{*}$ & $0.0079 *$ & & $0.0072^{*}$ & $0.0075^{*}$ & 0.0067 \\
\hline & $(0.0042)$ & $(0.0042)$ & $(0.0042)$ & $(0.0043)$ & & $(0.0042)$ & $(0.0042)$ & $(0.0050)$ \\
\hline \multirow[t]{2}{*}{ 2.year\#NAC } & $0.0102^{* * *}$ & $0.0111^{* * *}$ & $0.0096^{* * *}$ & $0.0107^{* * *}$ & $0.0097^{* * *}$ & & $0.0105^{* * *}$ & $0.0091^{* * *}$ \\
\hline & $(0.0014)$ & $(0.0016)$ & $(0.0016)$ & $(0.0017)$ & $(0.0015)$ & & $(0.0014)$ & $(0.0013)$ \\
\hline \multirow[t]{2}{*}{ 2.year\#SAS } & $0.0207^{* * *}$ & $0.0209^{* * *}$ & $0.0204^{* * *}$ & $0.0213^{* * *}$ & $0.0201 * * *$ & $0.0207^{* * *}$ & & $0.0200^{* * *}$ \\
\hline & $(0.0031)$ & $(0.0032)$ & $(0.0032)$ & $(0.0032)$ & $(0.0031)$ & $(0.0031)$ & & $(0.0031)$ \\
\hline \multirow[t]{2}{*}{ 2.year\#SSF } & $0.0077^{* *}$ & $0.0081^{* *}$ & $0.0080^{* *}$ & $0.0084^{* * *}$ & $0.0067^{* *}$ & $0.0077^{* *}$ & $0.0081^{* * *}$ & \\
\hline & $(0.0030)$ & $(0.0031)$ & $(0.0031)$ & $(0.0031)$ & $(0.0031)$ & $(0.0030)$ & $(0.0030)$ & \\
\hline \multirow[t]{2}{*}{$\mathrm{y}$} & 0.0004 & -0.0002 & 0.0003 & 0.0005 & 0.0006 & 0.0004 & 0.0004 & $0.0008^{*}$ \\
\hline & $(0.0005)$ & $(0.0005)$ & $(0.0005)$ & $(0.0006)$ & $(0.0005)$ & $(0.0005)$ & $(0.0005)$ & $(0.0004)$ \\
\hline Observations & 324 & 280 & 244 & 260 & 292 & 322 & 312 & 234 \\
\hline R-squared & 0.284 & 0.304 & 0.205 & 0.270 & 0.292 & 0.284 & 0.282 & 0.355 \\
\hline Number of countries & 162 & 140 & 122 & 130 & 146 & 161 & 156 & 117 \\
\hline Excluded region & None & EAS & ECS & LCN & MEA & NAC & SAS & SSF \\
\hline
\end{tabular}

Notes: Asterisks $*, * *, * * *$ denote significance at the 10, 5, and 1 percent level, respectively. All standard errors (in parenthesis) are clustered at the country level. Regional code is: East Asia \& Pacific (EAS), Europe and Central Asia (ECS), Latin America \& Caribbean (LCN), Middle East \& North Africa (MEA), North America (NAC), South Asia (SAS), sub-Saharan Africa (SSF). 


\section{Table 4: Fixed effects estimation}

Estimating equation: $g y_{i t}=\beta_{0}+\beta_{1} \cdot N R_{i} \cdot D_{t}+\sum_{j=1}^{J} \beta_{2 j} \cdot D_{t} \cdot R_{j}+c_{i}+$ error $_{i t}$

\begin{tabular}{|c|c|c|c|c|c|c|c|c|}
\hline \multirow[b]{2}{*}{ VARIABLES } & (1) & (2) & (3) & (4) & (5) & (6) & (7) & (8) \\
\hline & \multicolumn{8}{|c|}{ Unadjusted growth } \\
\hline \multirow[t]{2}{*}{ Constant } & $0.0151^{* * *}$ & $0.0148^{* * *}$ & $0.0150^{* * *}$ & $0.0149 * * *$ & $0.0154^{* * *}$ & $0.0150^{* * *}$ & $0.0145^{* * *}$ & $0.0164^{* * *}$ \\
\hline & $(0.0015)$ & $(0.0016)$ & $(0.0015)$ & $(0.0018)$ & $(0.0016)$ & $(0.0015)$ & $(0.0015)$ & $(0.0015)$ \\
\hline \multirow[t]{2}{*}{ 2.year\#totnatresrent } & $0.0525^{*}$ & $0.0545^{*}$ & 0.0281 & $0.0497^{*}$ & $0.0613^{* *}$ & $0.0525^{* *}$ & $0.0528^{* *}$ & $0.0880^{* *}$ \\
\hline & $(0.0266)$ & $(0.0285)$ & $(0.0300)$ & $(0.0282)$ & $(0.0289)$ & $(0.0266)$ & $(0.0266)$ & $(0.0386)$ \\
\hline \multirow[t]{2}{*}{ 2.year\#EAS } & 0.0036 & & 0.0053 & 0.0038 & 0.0030 & 0.0036 & 0.0036 & 0.0011 \\
\hline & $(0.0055)$ & & $(0.0056)$ & $(0.0055)$ & $(0.0056)$ & $(0.0055)$ & $(0.0055)$ & $(0.0058)$ \\
\hline \multirow[t]{2}{*}{ 2.year\#ECS } & $0.0276^{* * *}$ & $0.0275^{* * *}$ & & $0.0278^{* * *}$ & $0.0272^{* * *}$ & $0.0276^{* * *}$ & $0.0276^{* * *}$ & $0.0258^{* * *}$ \\
\hline & $(0.0071)$ & $(0.0071)$ & & $(0.0072)$ & $(0.0071)$ & $(0.0071)$ & $(0.0071)$ & $(0.0068)$ \\
\hline \multirow[t]{2}{*}{ 2.year\#LCN } & $0.0137^{* * *}$ & $0.0136^{* * *}$ & $0.0149^{* * *}$ & & $0.0133^{* * *}$ & $0.0137^{* * *}$ & $0.0137^{* * *}$ & $0.0119^{* *}$ \\
\hline & $(0.0044)$ & $(0.0044)$ & $(0.0045)$ & & $(0.0044)$ & $(0.0044)$ & $(0.0044)$ & $(0.0046)$ \\
\hline \multirow[t]{2}{*}{ 2.year\#MEA } & -0.0018 & -0.0021 & 0.0028 & -0.0012 & & -0.0018 & -0.0018 & -0.0084 \\
\hline & $(0.0089)$ & $(0.0092)$ & $(0.0090)$ & $(0.0091)$ & & $(0.0089)$ & $(0.0089)$ & $(0.0113)$ \\
\hline \multirow[t]{2}{*}{ 2.year\#NAC } & $-0.0141^{* * *}$ & $-0.0141^{* * *}$ & $-0.0141^{* * *}$ & $-0.0141^{* * *}$ & $-0.0141^{* * *}$ & & $-0.0141^{* * *}$ & $-0.0141^{* * *}$ \\
\hline & $(0.0000)$ & $(0.0000)$ & $(0.0000)$ & $(0.0000)$ & $(0.0000)$ & & $(0.0000)$ & $(0.0000)$ \\
\hline \multirow[t]{2}{*}{ 2.year\#SAS } & $0.0128^{* * *}$ & $0.0127^{* * *}$ & $0.0140^{* * *}$ & $0.0129 * * *$ & $0.0123^{* * *}$ & $0.0128^{* * *}$ & & $0.0109 * *$ \\
\hline & $(0.0043)$ & $(0.0044)$ & $(0.0042)$ & $(0.0043)$ & $(0.0044)$ & $(0.0043)$ & & $(0.0049)$ \\
\hline \multirow[t]{2}{*}{ 2.year\#SSF } & 0.0038 & 0.0036 & 0.0071 & 0.0042 & 0.0027 & 0.0038 & 0.0038 & \\
\hline & $(0.0066)$ & $(0.0066)$ & $(0.0064)$ & $(0.0066)$ & $(0.0066)$ & $(0.0066)$ & $(0.0066)$ & \\
\hline Observations & 324 & 280 & 244 & 260 & 292 & 322 & 312 & 234 \\
\hline R-squared & 0.237 & 0.244 & 0.135 & 0.222 & 0.253 & 0.236 & 0.234 & 0.339 \\
\hline Number of countries & 162 & 140 & 122 & 130 & 146 & 161 & 156 & 117 \\
\hline Excluded region & None & EAS & ECS & LCN & MEA & NAC & SAS & SSF \\
\hline
\end{tabular}

Notes: Asterisks $*, * *,{ }^{* *}$ denote significance at the 10, 5, and 1 percent level, respectively. All standard errors (in parenthesis) are clustered at the country level. Regional code is: East Asia \& Pacific (EAS), Europe and Central Asia (ECS), Latin America \& Caribbean (LCN), Middle East \& North Africa (MEA), North America (NAC), South Asia (SAS), sub-Saharan Africa (SSF). 
Table 5: Counterfactual scenarios by region

\begin{tabular}{ccccc}
\hline Region & \# Observations & $\frac{1}{N} \cdot \sum_{i=1}^{N} g y_{i 2}$ & $\sum_{i=1}^{N_{J}} \frac{N R_{i}}{N_{J}}$ & $C C=0.03 \cdot \sum_{i=1}^{N_{J}} \frac{N R_{i}}{N_{J}}$ \\
\hline EAS & 22 & 0.0258 & 0.07 & \\
ECS & 40 & 0.0169 & 0.05 & $0.21 \%$-point \\
LCN & 32 & 0.0323 & 0.05 & $0.15 \%$-point \\
MEA & 16 & 0.0276 & 0.19 & $0.57 \%$-point \\
NAC1 & 1 & 0.0260 & 0 & $0 \%$-point \\
SAS & 6 & 0.0376 & 0.05 & $0.15 \%$-point \\
SSF & 45 & 0.0270 & 0.13 & $0.29 \%$-point \\
\hline Full sample & 162 & 0.0313 & 0.09 & $0.27 \%$-point \\
\hline
\end{tabular}

Notes: Regional code is East Asia \& Pacific (EAS), Europe and Central Asia (ECS), Latin America \& Caribbean (LCN), Middle East \& North Africa (MEA), North America (NAC), South Asia (SAS), sub-Saharan Africa (SSF).

1) The only NAC country in our sample is Bermuda, which has no natural resources. Canada and the United States are dropped from the sample due to missing earthlight data. 


\section{Appendix Tables}

\section{Table A1: Fixed effects estimation}

Estimating equation: $g y_{i t}=\beta_{0}+\beta_{1} \cdot N R_{i} \cdot D_{t}+\sum_{j=1}^{J} \beta_{2 j} \cdot D_{t} \cdot R_{j}+\beta_{3} \cdot y_{i t-1}+c_{i}+$ error $_{i t}$

(1)

(2)

(3)

(4)

Adjusted growth

\begin{tabular}{|c|c|c|c|c|c|c|c|c|}
\hline VARIABLES & \multicolumn{8}{|c|}{ Adjusted growth } \\
\hline \multirow[t]{2}{*}{ Constant } & $0.0115^{* *}$ & $0.0168^{* * *}$ & $0.0131^{* * *}$ & $0.0100^{*}$ & $0.0096^{*}$ & $0.0114^{* *}$ & $0.0110^{* *}$ & $0.0084^{* *}$ \\
\hline & $(0.0045)$ & $(0.0053)$ & $(0.0048)$ & $(0.0056)$ & $(0.0050)$ & $(0.0045)$ & $(0.0045)$ & $(0.0042)$ \\
\hline \multirow[t]{2}{*}{ 2.year\#totnatresrent } & $0.0342^{* * *}$ & $0.0378^{* * *}$ & $0.0254 * * *$ & $0.0330^{* * *}$ & $0.0393^{* * *}$ & $0.0342^{* * *}$ & $0.0341^{* * *}$ & $0.0332^{*}$ \\
\hline & $(0.0087)$ & $(0.0083)$ & $(0.0095)$ & $(0.0092)$ & $(0.0091)$ & $(0.0087)$ & $(0.0087)$ & $(0.0180)$ \\
\hline \multirow[t]{2}{*}{ 2.year\#EAS } & $0.0133^{* * *}$ & & $0.0127^{* * *}$ & $0.0135^{* * *}$ & $0.0131^{* * *}$ & $0.0133^{* * *}$ & $0.0134^{* * *}$ & $0.0142^{* * *}$ \\
\hline & $(0.0035)$ & & $(0.0034)$ & $(0.0036)$ & $(0.0036)$ & $(0.0035)$ & $(0.0036)$ & (0.0039) \\
\hline \multirow[t]{2}{*}{ 2.year\#ECS } & $0.0317^{* * *}$ & $0.0320^{* * *}$ & & $0.0318^{* * *}$ & $0.0315^{* * *}$ & $0.0317^{* * *}$ & $0.0318^{* * *}$ & $0.0326^{* * *}$ \\
\hline & $(0.0031)$ & $(0.0030)$ & & $(0.0031)$ & $(0.0030)$ & $(0.0031)$ & $(0.0031)$ & $(0.0033)$ \\
\hline \multirow[t]{2}{*}{ 2.year\#LCN } & $0.0200^{* * *}$ & $0.0202^{* * *}$ & $0.0194^{* * *}$ & & $0.0198^{* * *}$ & $0.0200^{* * *}$ & $0.0201^{* * *}$ & $0.0207^{* * *}$ \\
\hline & $(0.0018)$ & $(0.0019)$ & $(0.0018)$ & & $(0.0018)$ & $(0.0018)$ & $(0.0018)$ & $(0.0022)$ \\
\hline \multirow[t]{2}{*}{ 2.year\#MEA } & $0.0143^{* * *}$ & $0.0139 * * *$ & $0.0150^{* * *}$ & $0.0145^{* * *}$ & & $0.0143^{* * *}$ & $0.0143^{* * *}$ & $0.0150^{* * *}$ \\
\hline & $(0.0043)$ & $(0.0044)$ & $(0.0042)$ & $(0.0043)$ & & $(0.0043)$ & $(0.0043)$ & $(0.0056)$ \\
\hline \multirow[t]{2}{*}{ 2.year\#NAC } & $0.0196^{* * *}$ & $0.0203^{* * *}$ & $0.0175^{* * *}$ & $0.0197^{* * *}$ & $0.0197^{* * *}$ & & $0.0197 * * *$ & $0.0210^{* * *}$ \\
\hline & $(0.0015)$ & $(0.0016)$ & $(0.0013)$ & $(0.0016)$ & $(0.0015)$ & & $(0.0015)$ & $(0.0027)$ \\
\hline \multirow[t]{2}{*}{ 2.year\#SAS } & $0.0252^{* * *}$ & $0.0258^{* * *}$ & $0.0236^{* * *}$ & $0.0254^{* * *}$ & $0.0251^{* * *}$ & $0.0252^{* * *}$ & & $0.0267^{* * *}$ \\
\hline & $(0.0036)$ & $(0.0037)$ & $(0.0034)$ & $(0.0037)$ & $(0.0036)$ & $(0.0036)$ & & $(0.0045)$ \\
\hline \multirow[t]{2}{*}{ 2.year\#SSF } & $0.0143^{* * *}$ & $0.0141^{* * *}$ & $0.0146^{* * *}$ & $0.0145^{* * *}$ & $0.0136^{* * *}$ & $0.0143^{* * *}$ & $0.0143^{* * *}$ & \\
\hline & $(0.0030)$ & $(0.0030)$ & $(0.0030)$ & $(0.0030)$ & $(0.0031)$ & $(0.0030)$ & $(0.0030)$ & \\
\hline \multirow[t]{2}{*}{$\mathrm{y}$} & $-0.0474^{* * *}$ & $-0.0500^{* * *}$ & $-0.0403^{* * *}$ & $-0.0478^{* * *}$ & $-0.0479 * * *$ & $-0.0474^{* * *}$ & $-0.0477^{* * *}$ & $-0.0521^{* * *}$ \\
\hline & $(0.0051)$ & $(0.0055)$ & $(0.0045)$ & $(0.0055)$ & $(0.0050)$ & $(0.0051)$ & $(0.0052)$ & $(0.0091)$ \\
\hline Observations & 324 & 280 & 244 & 260 & 292 & 322 & 312 & 234 \\
\hline R-squared & 0.655 & 0.688 & 0.581 & 0.645 & 0.669 & 0.655 & 0.655 & 0.677 \\
\hline Number of countries & 162 & 140 & 122 & 130 & 146 & 161 & 156 & 117 \\
\hline Excluded region & None & EAS & ECS & LCN & MEA & NAC & SAS & SSF \\
\hline
\end{tabular}

Notes: Asterisks $*,{ }^{* *},{ }^{* *}$ denote significance at the 10,5 , and 1 percent level, respectively. All standard errors (in parenthesis) are clustered at the country level. Regional code is: East Asia \& Pacific (EAS), Europe and Central Asia (ECS), Latin America \& Caribbean (LCN), Middle East \& North Africa (MEA), North America (NAC), South Asia (SAS), sub-Saharan Africa (SSF). 
Table A2: Fixed effects estimation with sample period 1993-2007

Estimating equation: $g y_{i t}=\beta_{0}+\beta_{1} \cdot N R_{i} \cdot D_{t}+\sum_{j=1}^{J} \beta_{2 j} \cdot D_{t} \cdot R_{j}+c_{i}+$ error $_{i t}$

\begin{tabular}{|c|c|c|c|c|c|c|c|c|}
\hline \multirow[b]{2}{*}{ VARIABLES } & (1) & (2) & (3) & (4) & (5) & (6) & (7) & (8) \\
\hline & \multicolumn{8}{|c|}{ Adjusted growth } \\
\hline \multirow[t]{2}{*}{ Constant } & $0.0188^{* * *}$ & $0.0187^{* * *}$ & $0.0187^{* * *}$ & $0.0187^{* * *}$ & $0.0190^{* * *}$ & $0.0188^{* * *}$ & $0.0184^{* * *}$ & $0.0192^{* * *}$ \\
\hline & $(0.0008)$ & $(0.0009)$ & $(0.0009)$ & $(0.0010)$ & $(0.0009)$ & $(0.0008)$ & $(0.0008)$ & $(0.0008)$ \\
\hline \multirow[t]{2}{*}{ 2.year\#totnatresrent } & $0.0244^{*}$ & $0.0254^{*}$ & 0.0103 & 0.0224 & $0.0276^{*}$ & $0.0244^{*}$ & $0.0246^{*}$ & $0.0501^{* *}$ \\
\hline & $(0.0134)$ & $(0.0144)$ & $(0.0137)$ & $(0.0141)$ & $(0.0148)$ & $(0.0134)$ & $(0.0134)$ & $(0.0202)$ \\
\hline \multirow[t]{2}{*}{ 2.year\#EAS } & $0.0100^{* * *}$ & & $0.0110^{* * *}$ & $0.0101^{* * *}$ & $0.0098^{* * *}$ & $0.0100^{* * *}$ & $0.0100^{* * *}$ & $0.0082^{* *}$ \\
\hline & $(0.0030)$ & & $(0.0030)$ & $(0.0030)$ & $(0.0031)$ & $(0.0030)$ & $(0.0030)$ & $(0.0032)$ \\
\hline \multirow[t]{2}{*}{ 2.year\#ECS } & $0.0203^{* * *}$ & $0.0202^{* * *}$ & & $0.0204^{* * *}$ & $0.0201^{* * *}$ & $0.0203^{* * *}$ & $0.0203^{* * *}$ & $0.0189^{* * *}$ \\
\hline & $(0.0038)$ & $(0.0038)$ & & $(0.0038)$ & $(0.0038)$ & $(0.0038)$ & $(0.0038)$ & $(0.0036)$ \\
\hline \multirow[t]{2}{*}{ 2.year\#LCN } & $0.0132^{* * *}$ & $0.0132^{* * *}$ & $0.0139 * * *$ & & $0.0131^{* * *}$ & $0.0132^{* * *}$ & $0.0132^{* * *}$ & 0.0119 *** \\
\hline & $(0.0022)$ & $(0.0022)$ & $(0.0022)$ & & $(0.0022)$ & $(0.0022)$ & $(0.0022)$ & $(0.0023)$ \\
\hline \multirow[t]{2}{*}{ 2.year\#MEA } & 0.0066 & 0.0065 & $0.0093^{* *}$ & 0.0070 & & 0.0066 & 0.0066 & 0.0018 \\
\hline & $(0.0046)$ & $(0.0048)$ & $(0.0046)$ & $(0.0047)$ & & $(0.0046)$ & $(0.0046)$ & $(0.0059)$ \\
\hline \multirow[t]{2}{*}{ 2.year\#NAC } & $0.0040^{* * *}$ & $0.0040^{* * *}$ & $0.0040^{* * *}$ & $0.0040^{* * *}$ & $0.0040^{* * *}$ & & $0.0040^{* * *}$ & $0.0040^{* * *}$ \\
\hline & $(0.0000)$ & $(0.0000)$ & $(0.0000)$ & $(0.0000)$ & $(0.0000)$ & & $(0.0000)$ & $(0.0000)$ \\
\hline \multirow[t]{2}{*}{ 2.year\#SAS } & $0.0120^{* * *}$ & $0.0119^{* * *}$ & $0.0127^{* * *}$ & $0.0121^{* * *}$ & $0.0118^{* * *}$ & $0.0120^{* * *}$ & & $0.0107^{* *}$ \\
\hline & $(0.0041)$ & $(0.0041)$ & $(0.0040)$ & $(0.0041)$ & $(0.0041)$ & $(0.0040)$ & & $(0.0043)$ \\
\hline \multirow[t]{2}{*}{ 2.year\#SSF } & $0.0076^{*}$ & $0.0075^{*}$ & $0.0095^{* *}$ & $0.0079^{*}$ & $0.0072^{*}$ & $0.0076^{*}$ & $0.0076^{*}$ & \\
\hline & $(0.0040)$ & $(0.0040)$ & $(0.0038)$ & $(0.0040)$ & $(0.0040)$ & $(0.0040)$ & $(0.0040)$ & \\
\hline Observations & 328 & 280 & 248 & 264 & 296 & 326 & 316 & 238 \\
\hline R-squared & 0.363 & 0.358 & 0.293 & 0.332 & 0.365 & 0.363 & 0.359 & 0.506 \\
\hline Number of countries & 164 & 140 & 124 & 132 & 148 & 163 & 158 & 119 \\
\hline Excluded region & None & EAS & ECS & LCN & MEA & NAC & SAS & SSF \\
\hline
\end{tabular}

Notes: Asterisks $*, * *,{ }^{* *}$ denote significance at the 10, 5, and 1 percent level, respectively. All standard errors (in parenthesis) are clustered at the country level. Regional code is: East Asia \& Pacific (EAS), Europe and Central Asia (ECS), Latin America \& Caribbean (LCN), Middle East \& North Africa (MEA), North America (NAC), South Asia (SAS), sub-Saharan Africa (SSF). 


\section{Table A3: Fixed effects estimation with resource dummy}

Estimating equation: $g y_{i t}=\beta_{0}+\beta_{1} \cdot N R_{i} \cdot D_{t}+\sum_{j=1}^{J} \beta_{2 j} \cdot D_{t} \cdot R_{j}+c_{i}+$ error $_{i t}$

\begin{tabular}{|c|c|c|c|c|c|c|c|c|}
\hline & (1) & (2) & (3) & $(4)$ & (5) & (6) & (7) & (8) \\
\hline VARIABLES & \multicolumn{8}{|c|}{ Adjusted growth } \\
\hline \multirow[t]{2}{*}{ Constant } & $0.0155^{* * *}$ & $0.0151^{* * *}$ & $0.0162^{* * *}$ & $0.0150^{* * *}$ & $0.0158^{* * *}$ & $0.0155^{* * *}$ & $0.0151^{* * *}$ & $0.0161^{* * *}$ \\
\hline & $(0.0008)$ & $(0.0009)$ & $(0.0008)$ & $(0.0010)$ & $(0.0009)$ & $(0.0008)$ & $(0.0008)$ & $(0.0009)$ \\
\hline \multirow[t]{2}{*}{ 2.year\#1[totnatresrent $>0$ ] } & $0.0115^{* * *}$ & $0.0095^{* *}$ & $0.0079 * *$ & $0.0171^{* * *}$ & $0.0115^{* * *}$ & $0.0115^{* * *}$ & $0.0115^{* * *}$ & $0.0121^{* * *}$ \\
\hline & $(0.0038)$ & $(0.0044)$ & $(0.0039)$ & $(0.0045)$ & $(0.0040)$ & $(0.0038)$ & $(0.0038)$ & $(0.0040)$ \\
\hline \multirow[t]{2}{*}{ 2.year\#EAS } & -0.0012 & & 0.0015 & -0.0056 & -0.0012 & -0.0012 & -0.0012 & -0.0017 \\
\hline & $(0.0042)$ & & $(0.0044)$ & $(0.0046)$ & $(0.0044)$ & $(0.0042)$ & $(0.0042)$ & $(0.0043)$ \\
\hline \multirow[t]{2}{*}{ 2.year\#ECS } & $0.0148^{* * *}$ & $0.0167^{* * *}$ & & $0.0096^{*}$ & $0.0149^{* * *}$ & $0.0148^{* * *}$ & $0.0148^{* * *}$ & $0.0142^{* * *}$ \\
\hline & $(0.0050)$ & $(0.0053)$ & & $(0.0050)$ & $(0.0051)$ & $(0.0050)$ & $(0.0050)$ & $(0.0051)$ \\
\hline \multirow[t]{2}{*}{ 2.year\#LCN } & 0.0053 & 0.0069 & $0.0082^{* *}$ & & 0.0053 & 0.0053 & 0.0053 & 0.0047 \\
\hline & $(0.0039)$ & $(0.0043)$ & (0.0039) & & $(0.0041)$ & $(0.0039)$ & $(0.0039)$ & $(0.0041)$ \\
\hline \multirow[t]{2}{*}{ 2.year\#MEA } & 0.0040 & 0.0059 & 0.0073 & -0.0013 & & 0.0040 & 0.0040 & 0.0034 \\
\hline & $(0.0048)$ & $(0.0052)$ & $(0.0049)$ & $(0.0053)$ & & $(0.0048)$ & $(0.0048)$ & $(0.0050)$ \\
\hline \multirow[t]{2}{*}{ 2.year\#NAC } & $0.0057^{* * *}$ & $0.0057^{* * *}$ & $0.0057^{* * *}$ & $0.0057^{* * *}$ & $0.0057^{* * *}$ & & $0.0057^{* * *}$ & $0.0057^{* * *}$ \\
\hline & $(0.0000)$ & $(0.0000)$ & $(0.0000)$ & $(0.0000)$ & $(0.0000)$ & & $(0.0000)$ & $(0.0000)$ \\
\hline \multirow[t]{2}{*}{ 2.year\#SAS } & 0.0013 & 0.0033 & 0.0049 & -0.0043 & 0.0013 & 0.0013 & & 0.0006 \\
\hline & $(0.0048)$ & $(0.0053)$ & $(0.0049)$ & $(0.0054)$ & $(0.0050)$ & $(0.0048)$ & & $(0.0050)$ \\
\hline 2.year\#SSF & 0.0018 & 0.0037 & 0.0053 & -0.0037 & 0.0018 & 0.0018 & 0.0018 & \\
\hline Constant & $(0.0051)$ & $(0.0055)$ & $(0.0051)$ & $(0.0056)$ & $(0.0053)$ & $(0.0051)$ & $(0.0051)$ & \\
\hline Observations & 324 & 280 & 244 & 260 & 292 & 322 & 312 & 234 \\
\hline R-squared & 0.416 & 0.420 & 0.342 & 0.405 & 0.409 & 0.416 & 0.412 & 0.503 \\
\hline Number of countries & 162 & 140 & 122 & 130 & 146 & 161 & 156 & 117 \\
\hline Excluded region & None & EAS & ECS & LCN & MEA & NAC & SAS & SSF \\
\hline
\end{tabular}

Notes: Asterisks $*, * *,{ }^{* *}$ denote significance at the 10, 5, and 1 percent level, respectively. All standard errors (in parenthesis) are clustered at the country level. Regional code is: East Asia \& Pacific (EAS), Europe and Central Asia (ECS), Latin America \& Caribbean (LCN), Middle East \& North Africa (MEA), North America (NAC), South Asia (SAS), sub-Saharan Africa (SSF). 